\title{
Asthma in primary care: Making guidelines work
}

\author{
Wayne Putnam MD ${ }^{1}$, Fred Burge $M D^{1}$, Sue Tatemichi MD ${ }^{2}$, Peter Twohig PhD ${ }^{2}$ \\ ${ }^{1}$ Department of Family Medicine, Dalhousie University, Halifax, Nova Scotia; \\ ${ }^{2}$ Department of Family Medicine, Dalhousie University, Frederiction, New Brunswick
}

\author{
W Putnam, F Burge, S Tatemichi, P Twohig. Asthma in \\ primary care: Making guidelines work. Can Respir J \\ 2001;8(Suppl A):29A-34A.
}

OBJECTIVE: To determine the views of family physicians regarding selected asthma recommendations from a Canadian practice guideline and the supporting evidence, and to identify issues needing further development if family physicians are to find guideline recommendations to be truly useful clinical tools.

SETTING: Four urban communities in Nova Scotia, Prince Edward Island and New Brunswick.

PARTICIPANTS: Twenty community family physicians representing different practice settings, and varying according to age and sex, were recruited to participate.

DATA COLLECTION: Four focus groups were held, each lasting $2 \mathrm{~h}$, at which recommendations from a published asthma guideline were presented for discussion on the applicability to their practices. The data were analyzed using a grounded theory method.

RESULTS: Physicians rely on clinical judgment in lieu of objective measures in diagnosing asthma and resist treating every exacerbation with steroids. They thought that the recommendations on smoking and patient education should have been stronger or more prominent. Patient noncompliance limits the usefulness of home peak flow measures. Topics such as allergy assessment and most pharmacological therapies triggered little discussion.

DISCUSSION: Asthma guideline developers and those interested in enhancing compliance with recommendations will need to attend to factors such as physician attitudes and beliefs on a variety of issues, including the use of objective measures and the availability of adequate resources to conduct the tests. Similarly, negative patient attitudes toward an increased use of corticosteroids suggest that a public education program would be most helpful regarding that group of recommendations.

Key Words: Asthma; Evidence-based medicine; Focus group interviews; Practice guideline

\section{Asthme et soins primaires : faciliter l'applica- tion des lignes de conduite}

OBJECTIFS : Recueillir le point de vue d'omnipraticiens sur certaines recommandations concernant l'asthme, tirées d'un guide thérapeutique canadien et fondées sur des preuves, en plus de cerner les aspects devant être améliorés pour que les omnipraticiens considèrent les recommandations relatives aux lignes de conduite comme des outils cliniques vraiment utiles.

MILIEU : Quatre centres urbains de la Nouvelle-Écosse, de l'Îledu-Prince-Édouard et du Nouveau-Brunswick.

SUJETS : Vingt omnipraticiens communautaires travaillant dans des milieux différents et présentant des caractéristiques différentes quant au sexe et à l'âge ont participé à l'étude.

COLLECTE DE DONNÉES : Il y a eu quatre réunions de groupe de consultation, d'une durée de deux heures chacune, au cours desquelles on a présenté des recommandations tirées d'un guide thérapeutique publié sur l'asthme à des fins de discussion sur leur applicabilité. Les données ont été analysées à l'aide d'une méthode théorique fondée.

RÉSULTATS : Les médecins se fient plus à leur jugement clinique qu'à des mesures objectives pour poser le diagnostic d'asthme et se montrent résistants au recours systématique aux stéroïdes en cas de crise. Ils estiment qu'on aurait dû mettre davantage l'accent sur les recommandations concernant l'abandon du tabagisme et l'éducation des patients. La non-observance des patients limite l'utilité des mesures du débit maximal à domicile. Les sujets comme l'évaluation des allergies et la plupart des traitements médicamenteux ont suscité très peu de discussion.

voir page suivante

Correspondence and reprints: Dr Wayne Putnam, Department of Family Medicine, Dalhousie University, Queen Elizabeth II Health Sciences Centre, Abbie J Lane Building, 8th floor, 5909 Veterans' Memorial Lane, Halifax, Nova Scotia B3H 2E2. Telephone 902-473-4740,

fax902-473-4760,e-mail Wayne.Putnam@Dal.CA 
DISCUSSION : Les personnes qui ont participe a l' elaboration des lignes de conduite sur l'asthme et celles qui sont intéressées à accroître le respect des recommandations devront tenir compte de facteurs comme l'attitude des médecins et leurs croyances sur diverses questions, comme le recours aux mesures objectives et la disponibi- lité des ressources pour effectuer les tests. De même, l'attitude défavorable des patients à l'égard d'une utilisation accrue des corticostéroïdes donne à penser que la mise sur pied d'un programme d'éducation du public s'avérerait fort utile pour ce type de recommandations.
$\mathrm{C}$ linical practice guidelines (CPGs) came into common use through the 1990s as a way of distilling sometimes conflicting and confusing evidence from clinical trials for practising physicians. Asthma guidelines for Canadian physicians were first published in 1990 (1), and updated in 1996 (2) and 1999 (3). The long process of CPG development from initial conception, through evidence gathering and synthesis, to recommendation construction and dissemination is really only the beginning. Once in the practice domain, there are many factors influencing physician and patient behaviour (4). The validation of guidelines by the intended users, most of them family physicians, is a step rarely undertaken, or if so, only explored superficially. The prior experience of two investigators was that, for a variety of reasons, community physicians may be sceptical of the applicability of nationally produced guidelines in their local setting (Putnam and Burge, unpublished data).

At the outset of the study in 1997, the objective was to determine the views of community family physicians regarding selected asthma recommendations and the supporting evidence from the 1996 Consensus Conference. A second objective was to identify important gaps in the evidence as possible research questions for primary care; these results are reported elsewhere (5).

\section{BACKGROUND}

A review of the English language literature, published before our work in 1997, on the application of asthma practice guidelines specifically in primary care yielded few relevant papers. Fried et al (6) reported that the use of objective measures of asthma severity was low. In a study of general practices in east London, United Kingdom, Feder et al (7) reported that the distribution of locally developed asthma guidelines through practice-based education changed the care of patients minimally. Neville et al (8) conducted a mailed survey of general practitioners and noted "a large gap between actual and recommended management".

There are no reported qualitative approaches to understanding the context in which family physicians try to implement asthma guidelines. Roghmann and Sexton (9) studied the prescribing of asthma medications over a six-month period and confirmed that adherence to practice guidelines was low. A variety of studies (10-13) provide conflicting evidence on the usefulness of educational and health care provider interventions for improving compliance with guidelines.

\section{METHODS}

Setting: Physicians were interviewed in focus groups in four urban communities (populations ranging from approximately 30,000 to 250,000 ) in Nova Scotia, Prince Edward Island and New Brunswick.
Participants: All focus group participants were selected through criterion sampling, considered suitable for small exploratory studies $(14,15)$. Twenty community family physicians who treat asthma regularly in typical private family practice settings were recruited for the focus groups. None saw patients in an asthma clinic. Eighty per cent of participants (four women, 12 men) were between 35 and 55 years of age, a time frame usually characterized by busy practices with adequate numbers of asthma patients. Written informed consent was obtained from each participant, and the protocol was approved by both the Dalhousie Faculty of Medicine Research Ethics Committee and the Dr Everett Chalmers Hospital Ethics Review Committee.

Data collection: Following published methods (16), four focus groups were conducted to discuss asthma practice guidelines with family physicians. Focus groups have been used in previous studies of asthma $(17,18)$ and clinical practice guidelines $(19,20)$.

Four focus groups, each lasting $2 \mathrm{~h}$, were held over a four-week period. No materials were distributed before the focus group session. Each focus group was facilitated by a physician researcher and observed by at least one other team member. On two occasions, a representative from Glaxo Wellcome Canada Inc, funder of the project, attended as an observer only.

Recommendations from the asthma guideline (2) were presented and the participants were asked to comment on the applicability of the recommendation to their own practices. The recommendations presented were selected by three of the authors on the basis of their importance to office-based primary care. The ensuing discussion was audiotaped for transcription, and field notes were taken by the research team.

Analysis: Grounded theory was used to analyze the focus group interviews. A grounded theory approach (21-24) is excellent for examining complex social realities, such as community-based family practice, which must give consideration to a wide range of resource and patient factors.

The transcriptions were analyzed by each investigator. Key words or phrases were identified that captured not only how physicians reported they behaved in relation to each guideline recommendation but also their thoughts and beliefs about asthma, and their feelings (frustration, irritation, satisfaction) about the guideline. Key words and phrases were then grouped based on similarity and conceptualized into categories, which became the building blocks for text coding within QSR NUD*IST (QSR International Pty Ltd, USA), a software package designed for qualitative data analysis. Coded text was evaluated across the focus groups to ensure that the entire range of experience was captured in addition to the dominant experience. 
TABLE 1

\begin{tabular}{|c|c|c|}
\hline Category & 1996 Asthma Consensus Conference (2) & 1999 Asthma Consensus Report (3) \\
\hline Diagnosis & 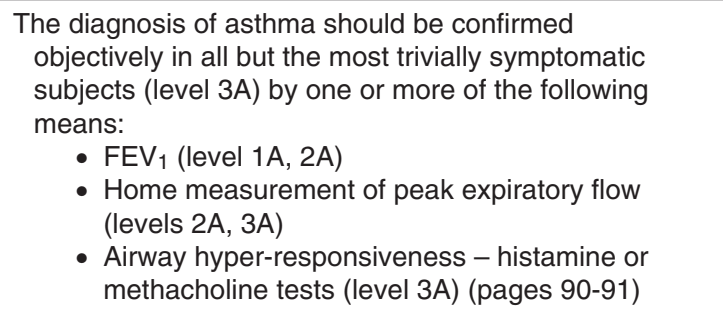 & $\begin{array}{l}\text { Objective measurements are needed to confirm the } \\
\text { diagnosis of asthma and to assess its severity in all } \\
\text { symptomatic patients (level III) using one of the } \\
\text { following: } \\
\text { - Spirometry (FEV }{ }_{1} \text { ) (level IV) } \\
\text { - Peak expiratory flow (level II) } \\
\text { - Airway hyper-responsiveness (level III) (page S4) }\end{array}$ \\
\hline Control & $\begin{array}{l}\text { Treatment of an exacerbation will depend upon the } \\
\text { severity of the episode and the nature of the mainte- } \\
\text { nance therapy; corticosteroids at increased doses, } \\
\text { either oral or inhaled, will be required (level 1A) (page 92) }\end{array}$ & \\
\hline Patient monitoring & $\begin{array}{l}\text { Peak expiratory flow measurements at home are } \\
\text { useful in adult patients who are poor perceivers } \\
\text { of airway obstruction or who have severe asthma } \\
\text { (level } 2 \mathrm{~A} \text { ) (page 92) }\end{array}$ & $\begin{array}{l}\text { Monitoring peak expiratory flow may be useful in some } \\
\text { patients, particularly those who are poor perceivers of } \\
\text { airflow obstruction (level III) (page S6) }\end{array}$ \\
\hline $\begin{array}{l}\text { Environmental } \\
\text { issues - tobacco }\end{array}$ & $\begin{array}{l}\text { Exposure to environmental tobacco smoke should } \\
\text { be avoided } \\
\text { Parents or caregivers of children with asthma } \\
\text { especially should be encouraged not to smoke } \\
\text { (level 2A) (pages 92-93) }\end{array}$ & $\begin{array}{l}\text { Exposure to environmental tobacco smoke should be } \\
\text { avoided (level III) } \\
\text { Pregnant women, and parents or caregivers of children } \\
\text { with asthma should be particularly encouraged not to } \\
\text { smoke (level II) (page S5) }\end{array}$ \\
\hline $\begin{array}{l}\text { Short acting } \\
\text { beta }_{2} \text {-agonists }\end{array}$ & $\begin{array}{l}\text { Short acting beta2-agonists used infrequently } \\
\text { (fewer than three times weekly, not including their } \\
\text { use to prevent exercise-induced symptoms) are } \\
\text { the drugs of choice for relief of asthma symptoms } \\
\text { that break through maintenance therapy with other } \\
\text { drugs (level 1A) (page 95) }\end{array}$ & $\begin{array}{l}\text { Regular anti-inflammatory medication should be used if } \\
\text { short-acting beta } \text { beagonists are used more than three } \\
\text { times a week in addition to their once-daily use to } \\
\text { prevent exercise-induced symptoms (level IV) (page S7) }\end{array}$ \\
\hline Aerosol device & $\begin{array}{l}\text { In general, MDIs with spacers can be used at any } \\
\text { age, while dry-powder inhalers provide adequate } \\
\text { drug delivery in most children by the age of five } \\
\text { years (level 2A) (page 96) } \\
\text { Home wet nebulizers to deliver asthma medications } \\
\text { are rarely, if ever, indicated in the management of } \\
\text { asthma in adults and older children (level 3E) } \\
\text { (page 97) }\end{array}$ & $\begin{array}{l}\text { With adequate teaching, adults and older children can } \\
\text { use any of the commercially available hand-held } \\
\text { inhalation devices } \\
\text { MDIs with spacers can be considered for all age groups, } \\
\text { and, specifically, MDIs with valved spacer and face } \\
\text { mask are advocated for young children and the elderly } \\
\text { Dry-powder inhalers can provide adequate drug delivery } \\
\text { for most children by the time they reach five years of } \\
\text { age (level II) } \\
\text { Wet nebulizers for home use are rarely indicated in the } \\
\text { management of asthma at any age (level III) (page S9) }\end{array}$ \\
\hline Patient education & $\begin{array}{l}\text { Education is an essential component of asthma } \\
\text { management (level 3A) (page 97) }\end{array}$ & $\begin{array}{l}\text { Asthma education is an essential component of asthma } \\
\text { therapy (level I) (page S6) }\end{array}$ \\
\hline
\end{tabular}

FEV 1 Forced expiratory volume in $1 \mathrm{~s} ;$ MDI Metered dose inhaler

\section{RESULTS}

Seven categories, listed in Table 1, elicited the greatest discussion in the four focus groups and yielded views that may be most helpful to those interested in enhancing the implementation of the newest asthma guideline. For comparison, the parallel statement from the 1999 Asthma Consensus Report summary of recommendations (25) is included. The findings within each theme are discussed more fully below. Direct quotations from participating physicians are italicized and represent generally held views. Recommendations (from the 1996 guideline) that generated little controversy or discussion are listed in Table 2.

Diagnosis: Physicians told the authors that they do not use objective measures for diagnostic purposes except in difficult to diagnose patients or those with atypical presentations.

\section{TABLE 2}

Categories of recommendations generally accepted with minimal discussion

Allergy assessment
Aeroallergens, dust mites, humidity
Occupational asthma
Corticosteroids (inhaled, oral)
Antiallergic agents
Long acting beta2-agonists
Theophyllines
Immunotherapy

I quite often will have...children and some asthmatics that are worse use a peak flow meter at home, on their own. But they're not using it as a 
In lieu of objective measures of airflow or a methacholine challenge test, they reported feeling that they were comfortable making the diagnosis on clinical grounds. Typically, family physicians believe that "it boils down to history and clinical examination".

Different reasons were offered to explain why objective measures are not more widely used. Physicians indicated that such testing does not change the initial clinical management plan. "It's not going to change my treatment of the patient. I'm going to treat the patient for their clinical condition". There was also scepticism about the reliability of testing in children and an uncertainty regarding the meaning of a negative pulmonary function test (PFT) when testing is done during a well period.

The focus group participants made numerous comments that related to resource issues. They spoke of long waits for spirometry or full PFTs, and the belief that frequent and universal testing wasted resources. If a patient has been wheezing and responds to treatment, "I don't need a PFT to tell me that person has asthma. I don't need to waste the resources of the community to do what I know". Physicians also expressed concern about patients' resources. Some would miss a day of work, and others lacked the needed transportation to get to a testing centre.

Control: There was general agreement with the recommendation for asthma control (Table 1) but resistance to the concept of treating every exacerbation with steroids. Physicians believed that there were many patients with asthma experiencing mild exacerbations after exposure to a trigger for whom a very brief course of bronchodilator was adequate. "GPs see the whole spectrum. From the [trivially symptomatic] athlete to the severe steroid-dependent. [We] are dealing with a different population".

Patient monitoring: Home monitoring with peak flow meters was considered to be an acceptable measure of airflow, best in compulsive patients, but this utility is constrained because of general patient noncompliance. Nevertheless, peak flow meters give a patient a 'sense of control' and are particularly useful in older children (for example, nine to 11 years of age) learning to manage their own condition. They are also useful in 'poor perceivers'.

Environmental issues: The wording of the recommendation on avoidance of smoking by parents of children with asthma was considered too weak. However, there was some ambivalence on the part of physicians regarding the approach to be taken with smoking parents. Some supported a tough, nononsense approach at the time of crisis (ie, child in an acute attack), whereas others would go gently at that time but broach the subject at a later visit with an offer to support smoking cessation.

I have this real mixed feeling between laying it on hard and heavy when their kid may be...admitted because of asthma so bad, versus
Short acting beta-agonists: Family physicians were very comfortable with the use of short acting beta-agonists but articulated some resistance to moving patients to steroids at such a low level of recommended beta2-agonist use (ie, less than three doses per week). This was attributed to patient reluctance, particularly in elderly patients. Older people who have had years of experience using beta-agonists were reported as being frequently skeptical because of the negative publicity regarding nonmedical use of steroids. A participant quoted an elderly patient as saying "[I've] managed, thank you very much, with my [salbutamol], I don't need that stuff".

Aerosol devices: The physicians were in general agreement that metered dose inhalers and dry-powder inhalers are best for most people most of the time. However, many spoke of a subset of patients who were reluctant to change and appeared to have a better response to aerosols during severe attacks.

Most people [admitted to hospital] are put on
aerosols. And maybe that's what we have to get away
from. Because certainly the message is there, when
you're real sick, you come and you get an aerosol.

Patient education: There was total agreement with the recommendation for patient education (Table 1) and criticism that it appeared at the end of the guideline. Participants said it should instead be "number 1".

Education is an essential component because it empowers and gives control to the patient. [Education] makes you feel good. It makes you feel in control. And when you feel in control with your disease, you manage it better.

The family physicians in the groups recognized that they have inadequate time to teach properly and do not do so routinely.

\section{DISCUSSION}

Focus group participants affirmed that asthma diagnosis and management are important primary care issues and that, generally, guidelines have a role in primary care. However, participants cited reliance on clinical acumen, uncertainty about the strength or meaning of particular recommendations, patient factors and local conditions as determinants that limited their ability to follow this guideline closely. There was very little disagreement with the general intent of most of the recommendations discussed. This is especially true for pharmacotherapy, where guideline statements are generally better supported by randomized, controlled trial evidence. Future guideline implementation efforts should focus on dealing with individual physician and local area barriers in addition to dissemination efforts through print 
TABLE 3

COPYRIGHT PULSUS GROUP INC, D DO NOT COPY

Barriers to guideline implementation efforts and possible remedies

\begin{tabular}{|c|c|c|}
\hline Categories & Barriers & Possible remedies \\
\hline \multirow[t]{3}{*}{ Diagnosis - Objective measures } & $\begin{array}{l}\text { Belief that objective measures offer no significant } \\
\text { advantage over clinical assessment, so are } \\
\text { wasteful of resources }\end{array}$ & Clear evidence of benefit in primary care patients \\
\hline & Waiting times & Increased access to spirometry \\
\hline & $\begin{array}{l}\text { Patients' loss of income if time off work; occasional } \\
\text { lack of transportation }\end{array}$ & Increased access to spirometry \\
\hline $\begin{array}{l}\text { Control - Use of steroids in all } \\
\text { exacerbations }\end{array}$ & $\begin{array}{l}\text { Belief that patients seen in primary care differ from } \\
\text { those included in drug trials (ie, latter have been } \\
\text { referred, are sicker) }\end{array}$ & $\begin{array}{l}\text { Evidence developed from trials of patients } \\
\text { representative of the full spectrum of asthma } \\
\text { in primary care }\end{array}$ \\
\hline $\begin{array}{l}\text { Threshold for changing } \\
\text { beta2-agonists to steroids, } \\
\text { at less than three doses per week }\end{array}$ & Patient reluctance, particularly in elderly patients & $\begin{array}{l}\text { Public and patient education regarding benefits } \\
\text { of steroids in asthma management }\end{array}$ \\
\hline Self-monitoring & $\begin{array}{l}\text { Patient noncompliance, except in 'compulsive' } \\
\text { patients }\end{array}$ & $\begin{array}{l}\text { Further exploration of patient views regarding } \\
\text { use of peak flow metres }\end{array}$ \\
\hline \multirow[t]{2}{*}{ Aerosol devices } & $\begin{array}{l}\text { Insistence by a small subset of patients that } \\
\text { aerosols work better for them than MDIs }\end{array}$ & $\begin{array}{l}\text { A clear description of the select group of patients } \\
\text { for whom aerosols have been shown to be } \\
\text { efficacious }\end{array}$ \\
\hline & & $\begin{array}{l}\text { An exploration of patients' reasons for belief } \\
\text { in superiority of aerosols may help to define } \\
\text { strategies to reduce their costly use }\end{array}$ \\
\hline Tobacco & $\begin{array}{l}\text { Ambivalence regarding hard- versus soft-sell } \\
\text { approach }\end{array}$ & $\begin{array}{l}\text { Clear evidence for what works in parents of } \\
\text { children with asthma }\end{array}$ \\
\hline Patient education & $\begin{array}{l}\text { Lack of time in office practice, eg, to teach proper } \\
\text { use of the MDI and role of anti-inflammatory } \\
\text { therapy }\end{array}$ & More community-based asthma education clinics \\
\hline
\end{tabular}

MDI Metered dose inhaler

media or continuing education. Table 3 summarizes the barriers described to us and some possible remedies.

Evidence: Some of the barriers dealt with the application of evidence in primary care. For example, physicians want to deal vigourously with smoking cessation in parents of children with asthma but are ambivalent about taking a hard line versus velvet glove approach at the acute encounter. There was no resolution of the dilemma, perhaps reflecting a lack of evidence of the effectiveness of either. A recently published report of a trial in Scotland involving 501 families reported that advising parents about the risks from passive smoking was ineffective in reducing exposure to environmental tobacco smoke (26). In fact, it might have made some parents less inclined to stop smoking (26). More frequently, however, physicians were concerned about the relevance of evidence to patients in their practices. They believe that much of the evidence that underpins guidelines is developed from trials that involve patients who are referred, and hence, sicker. The best example of this was the belief that not all patients seem to require steroids, reflecting the participants' view that some primary care patients may be different from those customarily included in trials. If their attitudes are to be changed, physicians must be made aware of any existing evidence that corticosteroids are helpful even in patients with mild, infrequent episodes of asthma.

Resources: Another major concern lay with the use of health care resources. Physicians uniformly and forcefully stated that they did not believe in the value of objective tests of airflow when they were comfortable with their clinical assess- ment. Although this ignores evidence published almost 30 years ago (27) and reinforced several times (28-30), demonstrating a poor association between clinical (symptoms and signs) and physiological measures of airway obstruction, it is consistent with findings in other primary care settings (6,31-33). Our participants expressed a concern on the part of physicians that they share responsibility for wise use of limited health care dollars. It is clear that family physicians will need to see more convincing evidence that objective testing changes outcomes for the patients predominantly seen in primary care to overcome their scepticism of its value.

With respect to the variety of community resources that support patient education, our study physicians expressed a surprising degree of enjoyment with this part of their asthma practice and appreciated the support they received. However, they expressed a need for more access to asthma education clinics where staff have more time than the average family physician to educate patients regarding the value of antiinflammatory treatment and the use of inhalers.

Patient factors: Patient factors were also significant barriers. Negative attitudes toward steroids in general, particularly in elderly patients, make it more difficult to initiate an anti-inflammatory regimen when bronchodilators seem to relieve symptoms. Peak flow meters are very helpful only if used with more consistency than most patients exhibit. Reluctance to change current therapy was cited for a small subset of patients who insist on the benefits of aerosols over metered dose inhalers. Consequently, successful strategies for implementing these particular recommendations will require 
intensive individual patient and public education to change attitudes.

Limitations: We recognize that our findings may not be applicable in all other parts of Canada. For example, findings relating to availability of resources may not be applicable in more urbanized areas and wealthier provinces. Highlighting the differences in accessibility to pulmonary function testing may serve some useful purpose in any future debate about the implementation of an asthma guideline. Another limitation may be that our participants misunderstood the intention of the guideline authors, as the discussions around the meaning of some of the recommendations suggest. However, we also note that guidelines distributed by publication or direct mail are vulnerable to this weakness in normal circumstances. On the basis of their understanding of the recommendations' meaning, physicians interpret and either act on or ignore them. With respect to the pharmaceutical representative's attendance at several focus groups, the opinion of the investigators present was that it made no difference to discussions of the guideline recommendations. Finally, we recognize that the participants might have reported opinions in the group that do not reflect their practices in the office, although we have no evidence to suggest that.

\section{SUMMARY}

The family physicians we interviewed accept most recommendations from the published asthma guidelines but believe that differences in patient characteristics and preferences are significant barriers to implementing many of them. The impact of the most recent update would be enhanced by attention to local issues including physician and patient attitudes, and availability of resources.

ACKNOWLEDGEMENTS: The authors gratefully acknowledge the financial support of Glaxo Wellcome Canada Inc for the project on which this paper was based. They also wish to thank the family physicians who willingly contributed their experience in the interviews, and Dr Dennis Bowie, Department of Medicine, Dalhousie University, for his advice during the planning phase of the project. We acknowledge the expertise of Natalie Dawson, whose meticulous transcription of the interview tapes was essential to our analysis.

\section{REFERENCES}

1. Hargreave FE, Dolovich J, Newhouse MT. The assessment and treatment of asthma: A conference report. J Allergy Clin Immunol 1990;85:1098-111.

2. Ernst P, FitzGerald JM, Spier S. Canadian Asthma Consensus Conference: Summary of recommendations. Can Respir J 1996;3:89-100.

3. Boulet L-P, Becker A, Berube D, Beveridge R, Ernst P, for the Canadian Asthma Consensus Group. Canadian Asthma Consensus Report, 1999. CMAJ 1999;161(11 Suppl):S1-61.

4. Evidence-Based Care Resource Group. Evidence-based care: 4. Improving performance: How can we improve the way we manage this problem? CMAJ 1994;150:1793-6.

5. Putnam W, Burge F, Tatemichi S, Twohig P. Using focus groups with community practitioners to define research questions for primary care. North American Primary Care Research Group 26th Annual Meeting. Montreal, November 4 to 7, 1998.

6. Fried RA, Miller RS, Green LA, Sherrod P, Nutting PA. The use of objective measures of asthma severity in primary care: A report from ASPN. J Fam Pract 1995;41:139-43.
7. Feder G, Grimiths C, Highton C, Eldridge S, Spence M, Southgate L.

Do clinical guidelines introduced with practice based education improve care of asthmatic and diabetic patients? A randomised controlled trial in general practices in east London. BMJ 1995;311:1473-8

8. Neville RG, Hoskins G, Smith B, Clark RA. How general practitioners manage acute asthma attacks. Thorax 1997;52:153-6.

9. Roghmann MC, Sexton M. Adherence to asthma guidelines in general practices. J Asthma 1999;36:381-7.

10. Tirimanna PRS, den Otter JJ, van Schayck CP, van Herwaarden CL, Folgering H, van Weel C. Evaluation of the suitability of weekly peak expiratory flow rate measurements in monitoring annual decline in lung function among patients with asthma and chronic bronchitis. Br J Gen Pract 1996;46:15-8.

11. Naish J, Sturdy P, Toon P. Appropriate prescribing in asthma and its related cost in east London. BMJ 1995;310:97-100.

12. Smeele IJ, Grol RP, van Schayck CP, van den Bosch WJ, van den Hoogen HJ, Muris JW. Can small group education and peer review improve care for patients with asthma/chronic obstructive pulmonary disease? Qual Health Care 1999;8:92-8.

13. Veninga CC, Lagerlov $P$, Wahlstrom R, et al. Evaluating an educational intervention to improve the treatment of asthma in four European countries. Drug Education Project Group. Am J Respir Crit Care Med 1999;160:1254-62.

14. Patton MQ. Designing qualitative studies. In: Qualitative Evaluation and Research Methods. Newbury Park: Sage Publications, 1990:169-86.

15. Morse JM. Strategies for sampling. In: Morse JM, ed. Qualitative Nursing Research: A Contemporary Dialogue. Newbury Park: Sage Publications, 1991:127-45.

16. Morgan DL. Focus Groups as Qualitative Research. Thousand Oaks: Sage Publications, 1997.

17. Munro JF, Haire-Joshu D, Fisher EB, Wedner HJ. Articulation of asthma and its care among low-income emergency care recipients. J Asthma 1996;33:313-25.

18. Kohler CL, Dolce JJ, Manzella BA, et al. Use of focus group methodology to develop an asthma self-management program useful for community-based medical practices. Health Educ Q 1993;20:421-9.

19. Fardy HJ, Jeffs D. Focus groups: A method for developing consensus guidelines in general practice. Fam Pract 1994;11:325-9.

20. Beaulieu M-D, Hudon E, Roberge D, Pineault R, Forte D, Legare J Practice guidelines for clinical prevention: Do patients, physicians and experts share common ground? CMAJ 1999;161:519-23.

21. Glaser BG, Strauss AL. The Discovery of Grounded Theory. New York: Aldine de Gruyter, 1967.

22. Glaser GB. Theoretical Sensitivity. Mill Valley: Sociology Press, 1978

23. Strauss A. Qualitative Analysis for Social Scientists. Cambridge: Cambridge University Press, 1987.

24. Strauss A, Corbin J. Basics of Qualitative Research. Newbury Park: Sage Publications, 1990.

25. Boulet L-P, Becker A, Berube D, Beveridge R, Ernst P. Summary of recommendations from the Canadian Asthma Consensus Report, 1999. CMAJ 1999;161(11 Suppl):S1-12.

26. Irvine L, Crombie IK, Clark RA, et al. Advising parents of asthmatic children on passive smoking: randomised controlled trial. BMJ 1999;318:1456-9.

27. McFadden ER Jr, Kiser R, DeGroot WJ. Acute bronchial asthma. Relations between clinical and physiologic manifestations. N Engl J Med 1973;288:221-5.

28. Rubinfeld AR, Pain MCF. How mild is mild asthma? Thorax 1977;32:177-81.

29. Burdon JG, Juniper EF, Killian KJ, Hargreave FE, Campbell EJ. The perception of breathlessness in asthma. Am Rev Respir Dis 1982;126:825-8.

30. Kikuchi Y, Okabe S, Tamura G, et al. Chemosensitivity and perception of dyspnea in patients with a history of near-fatal asthma. N Engl J Med 1994;330:1329-34.

31. Werk LN, Steinbach S, Adams WG, Bauchner H. Beliefs about diagnosing asthma in young children. Pediatrics 2000;105:585-90.

32. Picken HA, Greenfield S, Teres D, Hirway PS, Landis JN. Effect of local standards on the implementation of national guidelines for asthma: Primary care agreement with national asthma guidelines. J Gen Intern Med 1998;13:659-63.

33. Jans MP, Schellevis FG, van Hensbergen W, Dukkers van Emden T, van Eijk JT. Management of asthma and COPD patients: Feasibility of the application of guidelines in general practice. Int J Qual Health Care 1998;10:27-34 


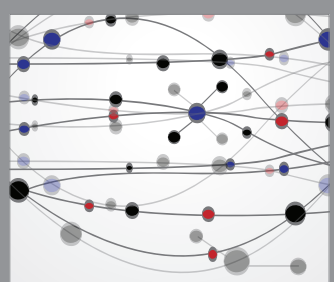

The Scientific World Journal
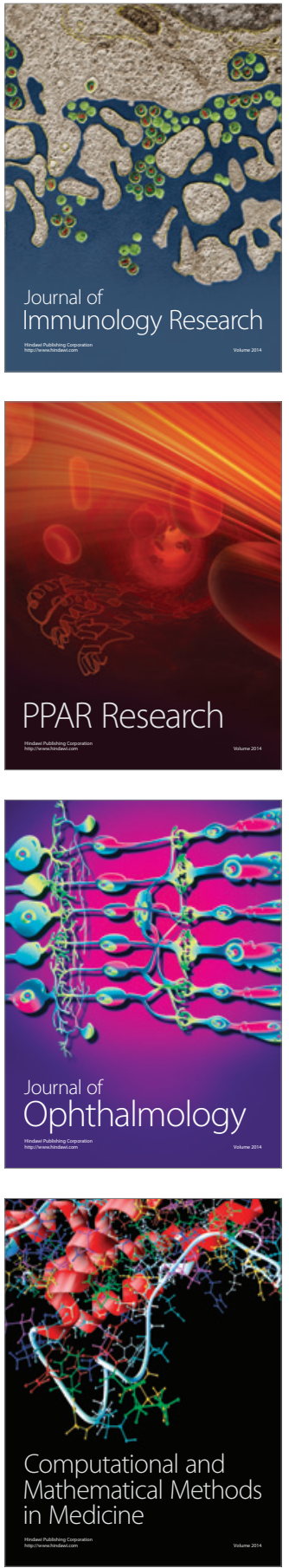

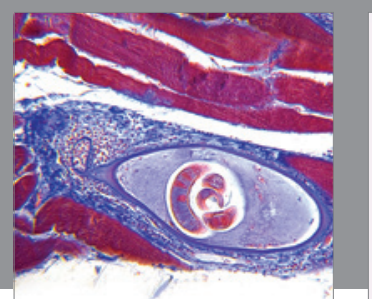

Gastroenterology Research and Practice

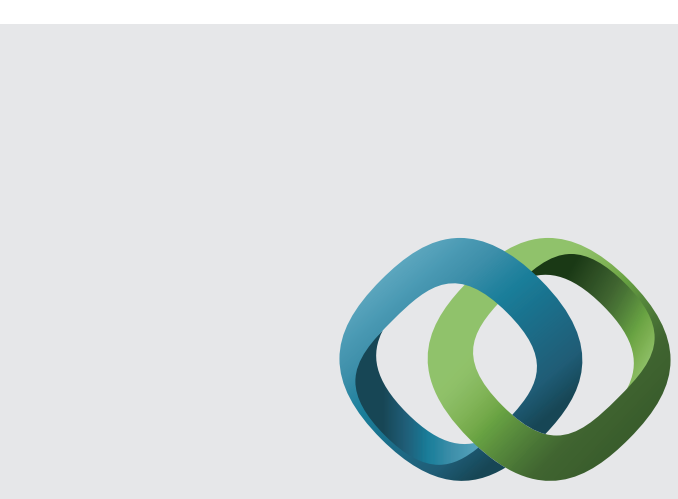

\section{Hindawi}

Submit your manuscripts at

http://www.hindawi.com
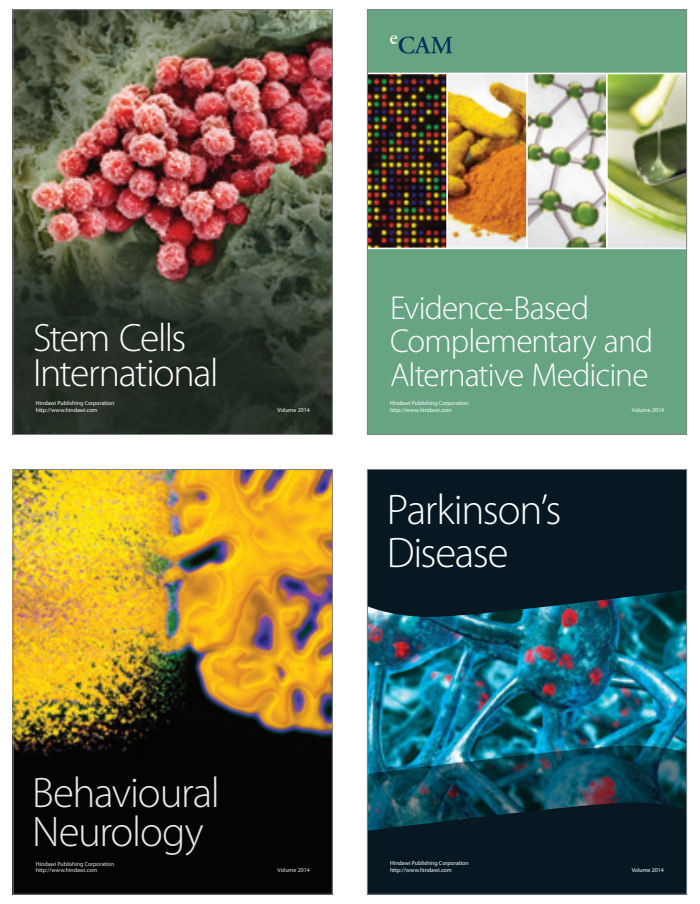
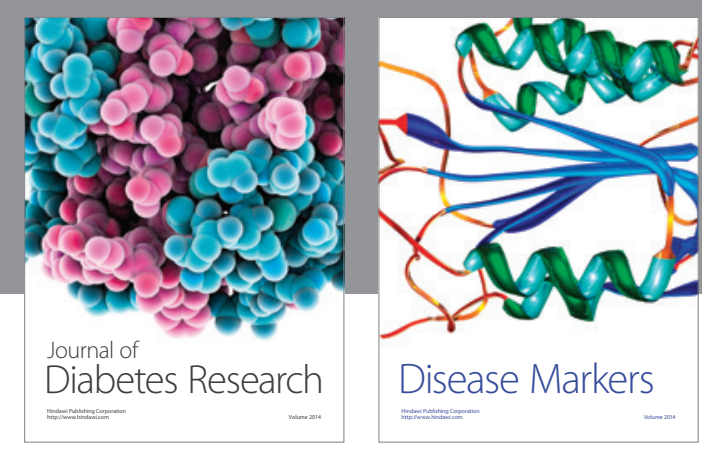

Disease Markers
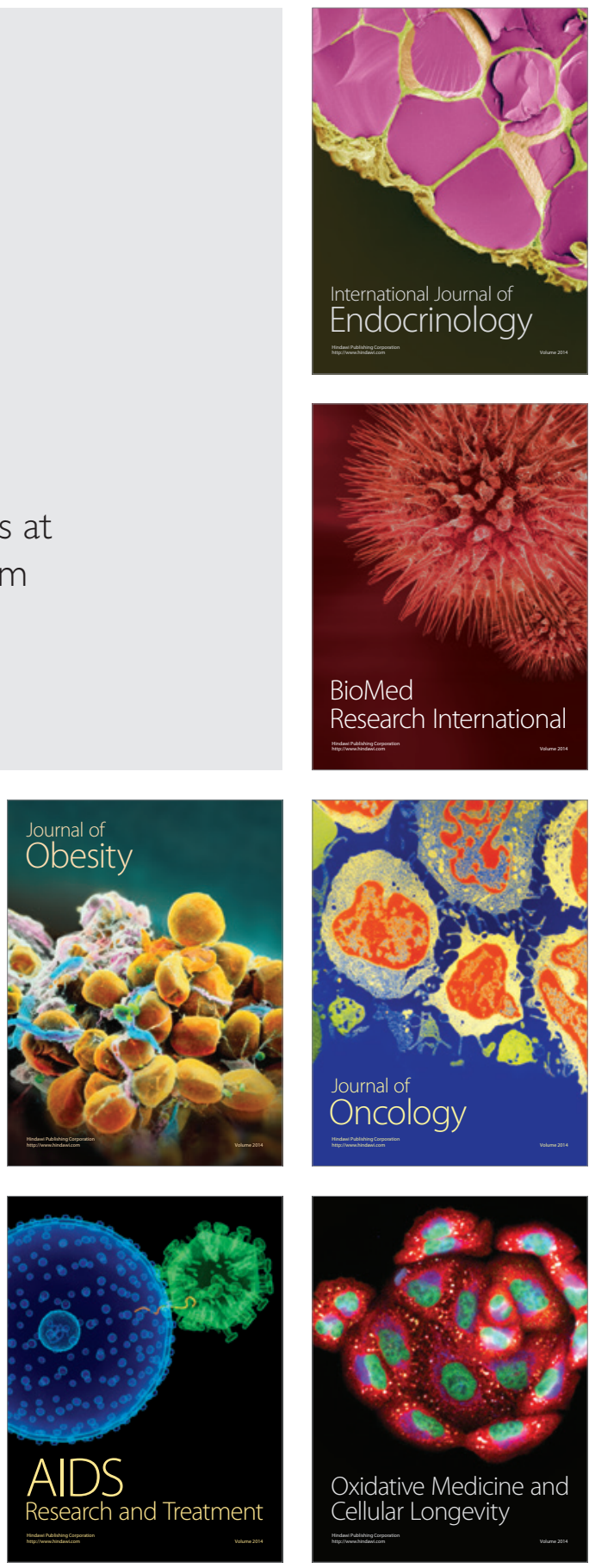